\title{
Sertão translated into Danish
}

The text transcribed here is originally a lecture given by Peter Poulsen, Danish writer and translator, during the event Discovering Brazilian Northeast with the Luiz Gonzaga's Music, which took place at Aarhus University on $26^{\text {th }}$ and $27^{\text {th }}$ of April, 2012. This event was promoted by the Brazilian Studies at Aarhus University, with the support of the Brazilian Embassy in Copenhagen.

The aim of this event was to introduce Luiz Gonzaga and his music, showing how this singer-songwriter has shaped a vision of the people and landscape of northeast Brazil.

The first day of the event included a showing of the film $O$ homem que engarrafava nuvens ('The Men who Bottled Clouds'), a documentary from 2009 by Lírio Ferreira, about the life of Humberto Teixeira, partner of Luiz Gonzaga and contributor, with Gonzaga, to the development of baião.

The following day included a round table session on the topic Luiz Gonzaga, the Sertão and the Sertanejo in the Brazilian culture as part of the Project "Lectures on Brazilian Studies". The round table session was led by Prof. Dr. Susanne Klengel, from Freie Universität Berlin, Prof. Dr. Bodil Marie Stavning Thomsen and Prof. Dr. Anne Line Dalsgård, both from Aarhus University and contained the following lectures: 'The Music of Luiz Gonzaga and the Creation of Northeast Brazil' by Prof. Dr. Vinicius Mariano de Carvalho, AU; 'Social and Economic Characteristics of the North-East of Brazil' by Prof. Dr. Steen Fryba, Alborg University; Luiz Gonzaga in the Brazilian Cinema' by Julia Machado, Ph.D Student AU and 'Sertão translated into Danish' by Peter Poulsen, translator of Guimarães Rosa's Grande Sertão: Veredas into Danish.

Brasiliana - Journal for Brazilian Studies. Vol. 1, n.1 (Sept. 2012). ISSN 2245-4373. 
The lectures were preceded by a reading performance of parts of Morte e Vida Severina, by João Cabral de Mello Neto, prepared by $1^{\text {st }}$ year Bachelor students of Brazilian Studies at AU and closed with a Forró workshop, both organized by Fernanda Gláucia Pinto, Foreign Lecturer of Brazilian Studies at AU.

Brasiliana is honored to be able include the publication of the transcription of Peter Poulsen's lecture in its first issue.

\section{Sertão translate into Danish - Peter Poulsen}

I've been asked to make this speech in English and I shall try to do so, even though my English has its clear limitations.

Moreover the subject of the speech which is my translation into Danish of the Brazilian novel Grande Sertão: Veredas by João Guimarães Rosa complicates the matter a little further.

For those of you who haven't read the novel and don't know its significance in Brazilian literature let me shortly introduce the author and his work.

João Guimarães Rosa was born in 1908 in Cordisburgo, Minas Gerais, and died as early as 1967. He studied medicine and functioned some years as a doctor in his homelands. Later he became writer and for some years he functioned as a Brazilian diplomat in Germany and a few other European countries.

His first book was printed in 1946. It was a collection of short stories called Sagarana. Ten years later, in 1956, he published another collection of short stories, Corpo de Baile, and the same year his first and only novel Grande Sertão: Veredas.

Later he published a few more short stories, and that was all.

Brasiliana - Journal for Brazilian Studies. Vol. 1, n.1 (Sept. 2012). ISSN 2245-4373. 
Grande Sertão: Veredas almost at once became a legend - first in Brazil and shortly afterwards the rumor began to spread all over the world and little by little translations emerged in countries which took an interest to what was going on in Brazil.

Not as fast as we sometimes experience when a great novel sees the light of the day - simply because the work is a big challenge for any translator into any language. Its leaping thoughts, its sudden changes from one subject to another, all its neologisms, its distorted syntax and unconventional rhythmic approach are not easy to cope with when you have to recreate or transplant this narrative into another soil.

Already the title of the novel represents a problem for translators. Grande Sertão, Big Sertão. There is no word for sertão in most other languages and no sertões outside Brazil and some of its neighbor's countries. Sertão in this novel is the widespread backlands of the northern Brazil, a sometimes arid, sometimes wooded, sometimes mountainous territory with small and big rivers, creeks and lakes, vast grazing grounds, pastures and deserts among each other. Plenty of wildlife, cattle, horses and a richness of vegetation. Sertão is also a word loaded with associations and hidden feelings.

And what about veredas? It's not oasis, since sertão is not desert. Veredas are humid, but not swamp. The Portuguese-English Dictionary translates it as path, lane or walk.

As you can see, it's necessary for the translator to invent another title for the book, a title which cannot contain the main words of the original.

Different translators offer different solutions to the problem and many of them focus on one of the main aspects of the story. In my Danish translation I've chosen the faustian aspect and called it Djævelen på vejen, "The Devil on the Road", referring to Rosa's enchanting epigraph: "The devil on the road $\backslash$ in the middle of the whirlwind."

What is the novel all about? Let me try to give you a vague idea.

Brasiliana - Journal for Brazilian Studies. Vol. 1, n.1 (Sept. 2012). ISSN 2245-4373. 
As the curtain goes up we meet and elderly gentleman sitting in a basket chair in front of his farmhouse, his fazenda, somewhere in the backlands, in the Brazilian sertão, talking to a younger man, a stranger from one of the littoral metropolis of the country visiting the area for his first time. This young man is the reader of the novel and the elderly gentleman, senhor Riobaldo, is its voice.

The novel is a long uninterrupted monologue from its first: nonada till its ultimate: travessia. Five hundred pages more or less.

There is a very intimate relationship between text and reader. Once in a while Riobaldo even asks the reader about his opinion: does the devil exist or not? And he doesn't wait for the answers but answers the question himself, and then goes on with his long and surprising story.

It is a love story - a very intricate love story I should say breaking with some of the normal ideas of what love is (I shall not go into details for the sake of those who haven't yet read the novel), a war story generated by a vendetta, and an ode to the great Sertão, its people, its nature told by a self-made man who was born there, who has always lived there and who shall probably die there. Fate has made him a jagunço another untranslatable word - member of an armed gang riding around in the sertão driving cattle from one spot to another, fighting other gangs or hiding from the government troops which are trying to intervene, control and dominate the area. Jagunços are outlaws now and then hired by big estate owners for various purposes.

Little by little Riobaldo gains more and more credit among his fellow jagunços and suddenly one day he is elected chief of his gang with the name Urutu Branco, the white viper or snake.

Riobaldo tells his life story from the very beginning to the present moment, but not in chronological order: "To tell in order", he explains, "after a ruler, is only possible 
when things are without significance. When I think of what I have experienced real strongly, joy or pain, then today I think that each time I became another person than I was. What happened, I had no influence over. That is my way of telling, I believe. You are as kind as to listen to me. There are long gone moments which are much more important than others more recent. You are aware of that, of course." Here Riobaldo explains the composition of Rosa's novel.

There has been, at least, two major trends in Brazilian literature of the past century: a modernistic and a regionalistic trend.

Modernism broke through in the early 1920 with the Semana de Arte Moderna, Week of Modern Art, in São Paulo. Brazilian modernism was strongly influenced by various European avant-garde movements and broke with all conservative trends - for a few years at least - and tried to create new ways of doing things and a new approach to Brazilian reality. The regionalist trend represented, as the name reveals, a local approach describing everyday life and political conditions somewhere in the vast country.

Rosa's novel is a paradox. It's both a modernistic and a regionalistic work. The subject is local, but its style is completely different from all other works describing certain regions, at the same time it's far from the mannerisms of every avant-garde - it introduces its own conditions and creates its very own way of speaking. And that is the way it becomes modernistic or what you'd prefer to call it. One can say that Rosa became his own movement. He has create his own very referential prose using what comes into his mind in the moment of writing and creating new Portuguese expressions such as cair na lordeza about a very bumptious person - directly translated it would be: to fall into "lordness", which nobody in the world says, except Riobaldo, who also puts nouns in superlative and says coisíssima nenhuma: "nothingst" - a charming expression in Portuguese, but indigestible in English or Danish. Riobaldo's way of speaking doesn't

Brasiliana - Journal for Brazilian Studies. Vol. 1, n.1 (Sept. 2012). ISSN 2245-4373. 
follow normal rules. Somewhere he must have heard the English word lord, whereupon he makes his new Portuguese noun: lordeza. There are many such examples in this work.

Rosa is both, the reader and the writer, the educated townsman and the self-made sertanejo.

When I visited Brazil for the first time, more than forty years ago, Grande Sertão: Veredas already had a mythological status among Brazilians who considered it very difficult to read and hard to understand. It had a reputation nor unlike Joyce's "Ulysses" or even "Finnegans Wake". As a foreigner with, at that time, a very limited knowledge of Portuguese you became scared even to think of reading the novel.

Almost two decades passed on before I dared to start. I must admit that in the beginning it was very difficult and strange. To enter the sertão was like landing on a far planet with its own codex, its own words and a very strange population - with few similarities between it and the population of this planet. But after a while the differences and with them the difficulties began to disappear. You could call it a process of integration.

As a reader you become "riobaldonized" and during that process you suddenly realize that the mere thought of reciprocating is no impossibility. From the very moment you are within the spell of Riobaldo as a human and as a speaker the novel becomes straight forward and understandable. When I had first read and later translated this overwhelming book I had the feeling of having travelled through the Brazilian soul and that is had mixed up with my own.

Translated woks can be compared to vegetation - they are like seeds of plants transported from one biotope and sown in another. If they survive and begin to grow they become the same plants as they were but under new circumstances. They become independent examples of their own kind and enter in dialogue with their new

Brasiliana - Journal for Brazilian Studies. Vol. 1, n.1 (Sept. 2012). ISSN 2245-4373. 
surroundings. The words of Rosa translated into Danish words and sown in Danish minds are still a Brazilian novel but also become a Danish one which takes place in a Danish sertão grown out of the Brazilian. You cannot place it on the map, but you can certainly place it in mind.

Translating Rosa I become more and more aware of this aspect of translation. The Devil on the Road is not only a translation of a principal work from Brazilian literature, it is also an independent Danish novel, the poor Brazilians are blissfully ignorant of an novel living its own life between Danish novels and Danish readers. Translations are multiplications. There are several Grande Sertão: Veredas around the world with each their place in different national literatures.

Before I finish this speech I feel obliged to break the rules. In order to give you an idea of how it all sounds when Riobaldo speaks Danish, I have to read a short sequence from my translation. For those of you knowing Danish, it is not a problem and for the rest of you I deeply apologize, but it can serve as a comfort that you shall at least get an idea of what Riobaldo sounds like in his new surroundings.

I shall not read one of the dramatic sequences, on the contrary. I've chosen some of the silent, humble scenes. After a big gathering and a moveable feast where a vast number of jagunços were gathered they find together in their original platoons and part in different directions.

Reading - (on the main page of the article, click on Article Tools, Supplementary files, to hear Peter Poulsen's reading from page 201 to 203 of the Danish version of Grande Sertão: Veredas - Djævelen på vejen. Copenhagen: Gyldendal, 1997)

Brasiliana - Journal for Brazilian Studies. Vol. 1, n.1 (Sept. 2012). ISSN 2245-4373. 
Of course I could have told about my research and my travels in the sertão in order to see some of the locations of this exceptional novel - as it was such a beautiful experience and undoubtedly helped me through some of the difficult passages. But I did not, since the main reason I completed the job - it took me almost five years - was in fact Riobaldo himself. One day his way of speaking and thinking also became mine, and from that moment it was a question of patience and regular work. There is still a bit of Riobaldo's soul mixed up with my own. And I hope it will stay there as long as I live.

Peter Poulsen, 27th April 2012 